\title{
Transamination Reactions in Uredospores of Puccinia helianthi
}

\author{
BY J. E. SMITH \\ Department of Applied Microbiology and Biology, Royal College of Science and \\ Technology, Glasgow
}

(Received 17 April 1962)

SUMMARY

Various transamination reactions were observed in germinating uredospores of Puccinia helianthi Schw. The localization and kinetic properties of glutamate-aspartate transaminase were examined. The presence of these transaminase enzymes in the uredospores suggests that the uredospore could synthesize a large number of amino acids.

\section{INTRODUCTION}

Since the discovery of enzymic transamination in pigeon breast muscle by Braunstein \& Kritzmann (1987) many transamination reactions have been studied in various organisms including fungi. In Neurospora crassa there are at least four transaminases which show specificity for $\alpha$-ketoglutarate (Fincham \& Boulter, 1956) and $\alpha$-keto- $\beta$-methylvalerate and $\alpha$-keto-isovalerate have been shown to transaminate readily with leucine and phenylalanine (Wagner \& Ifland, 1956; Wagner, Berquist \& Karp, 1958). Sanwal (1958) showed that in cell-free extracts of Fusarium lycopersici some 10 or 11 amino acids underwent transamination with $\alpha$-ketoglutarate. In Blastocladiella emersonii an alanine glyoxylate transaminase has been demonstrated and purified (McCurdy \& Cantino, 1960). Saccharomyces cerevisiae can transaminate several amino acids (Bigger-Gehring, 1955), and it seems likely that there is more than one transaminase responsible for these reactions (Sentheshanmuganathan, 1960). The present paper gives the results of an examination of the scope of transamination reactions in germinating uredospores of the obligate rust parasite Puccinia helianthi Schw.

\section{METHODS}

\section{Organism and enzyme preparations}

Uredospores were collected from plants of Helianthus annuus var. Foundation (seeds of which were kindly given by Co-operative Vegetable Oils Ltd., Manitoba, Canada) inoculated with Puccinia helianthi. The spores were placed in small dry vials (about $300 \mathrm{mg} . / 5 \mathrm{ml}$. vial) which were tightly corked and stored at $-10^{\circ}$. Under these conditions uredospores can be stored for several months with little loss in viability (Sackston, 1960).

Uredospores were brushed evenly over the surface of water-filled Visking tubes, which had previously been soaked in warm water for $6 \mathrm{hr}$., and the spores allowed to germinate in a covered glass tank for $20 \mathrm{hr}$. To aid the germination a phenol 
solution $\left(5 \times 10^{-4} \mathrm{M}\right)$ was introduced into the moisture-saturated atmosphere on strips of filter paper. Phenol stimulates germination and in common with coumarin (Farkas \& Ledingham, 1959) is sufficiently volatile to be active across an air gap. The resulting mat of mycelium was carefully removed, rinsed in tapwater, and blotted dry.

The particulate fraction was isolated by grinding the germinated spores and an equal weight of acid-washed powdered glass for 1 min. in a chilled mortar with a solution containing $0.6 \mathrm{M}$-sucrose $+0.05 \mathrm{M}$-potassium phosphate $+0.005 \mathrm{M}$-ethylenediaminetetra-acetic acid (EDTA), previously adjusted to $\mathrm{pH} 7 \cdot 8$ with $\mathrm{N}-\mathrm{NaOH}$. The homogenate was passed through several layers of moist butter muslin and clarified by centrifugation at $1000 \mathrm{~g}$ for $10 \mathrm{~min}$. in an M.S.E. 'High-Speed 17 ' refrigerated centrifuge to remove coarse cell debris and nuclei. The particulate fraction was then sedimented from the supernatant fluid by centrifugation at $20,000 \mathrm{~g}$ for $30 \mathrm{~min}$. The deposit was suspended in the extraction medium, resedimented and then suspended in a small volume of $0.6 \mathrm{M}$-sucrose in $0.05 \mathrm{M}$-phosphate buffer ( $\mathrm{pH} \mathrm{7.9}$ ).

\section{Assay of enzyme activities}

Transaminase activity was assayed by measuring quantitatively the appearance of the new amino acid on paper chromatograms. The reaction system contained 0.4 $\mathrm{ml}$. enzyme preparation, $0.1 \mathrm{ml}$. (30 $\mu$ mole) $\alpha$-keto acid, $0.05 \mathrm{ml}$. (10 $\mu$ mole) amino acid, $0.05 \mathrm{ml}$. (1 $\mu$ mole) pyridoxal phosphate and potassium phosphate buffer ( $\mathrm{pH} \mathrm{8.0}$ ) to a final volume of $1.0 \mathrm{ml}$. Where DL-isomers were used the substrate concentration was doubled. A reference control was run with the same mixture but lacking the amino acid donor. Incubations were carried out at $34^{\circ}$ and the reaction stopped by immersing the tubes in boiling water for $3 \mathrm{~min}$. Denatured proteins were removed by centrifugation at $3000 \mathrm{~g}$ for $10 \mathrm{~min}$. The amino acid components were separated by one-dimensional ascending paper chromatography on Whatman No. 1 filter paper by using either $80 \%$ phenol or $n$-butanol + pyridine + water $(3+2+1 \cdot 5$ by vol.) as solvents. The amino acids were located by spraying with $0.25 \%$ ninhydrin in $95 \%$ ethanol in water. The individual coloured spots were identified by their known $\boldsymbol{R}_{f}$ values carefully cut out and eluted overnight at $2^{\circ}$ in $50 \%$ ethanol in $0.025 \mathrm{M}$-phosphate buffer (pH 6.5). The absorption of the eluted colours at $570 \mathrm{~m} \mu$ was determined. Background corrections were made by cutting a comparable section of paper from the reference control, eluting it, measuring the absorption of the solution at $570 \mathrm{~m} \mu$ and subtracting this value from the absorption of the amino acid complex. Amino acid solutions of known concentration were subjected to this procedure and standard curves obtained for each amino acid.

A unit of enzyme activity is defined here as the amount of enzyme required to produce by transamination $0 \cdot 1 \mu$ mole acid/hr. $/ \mathrm{mg}$. protein.

The amount of protein in solution was calculated from the optical density of the enzyme preparations at $260 \mathrm{~m} \mu$ and $280 \mathrm{~m} \mu$ (Adams).

\section{Range of transamination}

\section{RESULTS}

Twenty-two amino acids were tested qualitatively and quantitatively for ability to transfer their amino group to $\alpha$-ketoglutarate in the presence of a washed particulate fraction from germinated uredospores. It was not found necessary to dialyse 
the extracts since preliminary experiments showed that there were no free amino acids present which would interfere with the chromatographic analysis. Positive transamination occurred with phenylalanine, $\gamma$-aminobutyric acid, arginine, asparagine, valine, tyrosine, aspartic acid, lysine, alanine, isoleucine, leucine, tryptophan and methionine (Table 1). With the exception of aspartic acid the transamination activities were low. In the case of methionine and tryptophan where extremely low transamination rates were obtained the results were always consistently higher (2-3 times) than the reference control. When the extract was dialysed for $18 \mathrm{hr}$. against de-ionized water at $1^{\circ}$ the ability to transaminate with tryptophan and methionine was lost and with asparagine and leucine was decreased to trace values.

Table 1. Transaminase activity of a particulate fraction from uredospores of Puccinia helianthi

The reaction system contained: $10 \mu$ mole amino acid; $30 \mu$ mole potassium $\alpha$-ketoglutarate; $1 \mu$ mole pyridoxal phosphate; $0.4 \mathrm{ml}$. enzyme suspension and $40 \mu \mathrm{mole}$ potassium phosphate buffer containing $0 \cdot 1 \%(\mathrm{v} / \mathrm{v})$ Nonidet $\mathrm{P} 40, \mathrm{pH} 7 \cdot 9$. Total volume 1 ml., temp. $32^{\circ}$.

$\begin{array}{lc}\text { Amino group donors } & \begin{array}{c}\text { Units of } \\ \text { activity }\end{array} \\ \text { L-Lysine } & 2 \cdot 50 \\ \text { L-Alanine } & 0 \cdot 50 \\ \text { L-Isoleucine } & 0 \cdot 61 \\ \text { L-Leucine } & 0 \cdot 57 \\ \text { Glycine } & - \\ \text { L-Citrulline } & - \\ \text { L-Proline } & - \\ \text { L-Phenylalanine } & 0 \cdot 65 \\ \gamma \text {-Amino-butyric acid } & 0 \cdot 70 \\ \text { L-Arginine } & 0 \cdot 46 \\ \text { L-Asparagine } & 0 \cdot 76\end{array}$

$\begin{array}{lc}\text { Amino group donors } & \begin{array}{c}\text { Units of } \\ \text { activity }\end{array} \\ \text { L-Serine } & - \\ \text { L-Histidine } & - \\ \text { L-Aspartic acid } & 12 \cdot 50 \\ \text { L-Ornithine } & - \\ \text { L-Valine } & \mathbf{0 \cdot 4 5} \\ \text { L-Methionine } & \mathbf{0 \cdot 2 0} \\ \text { L-Tyrosine } & \mathbf{0 \cdot 8 0} \\ \text { L-Cysteine } & - \\ \text { L-Cystine } & - \\ \text { L-Tryptophan } & 0 \cdot 10 \\ \text { L-Threonine } & -\end{array}$

\section{Localization of transaminase activity}

Since the particulate fractions used in these experiments were thoroughly washed in an isotonic medium to remove any cytoplasmic enzymes which may have adhered to the surface of particles during the extraction procedure, it is considered that the transaminase activity associated with the particles is most probably derived from particulate-bound enzymes. Furthermore, the glutamate-aspartate transaminase could be quantitatively released and solubilized from the particles by treatment with Nonidet P40 (Shell Chemical Co., Ltd., Glasgow) a non-ionic detergent. The ability of this detergent to free particulate-bound enzymes has previously been demonstrated for plant tissue (Smith, 1962). The soluble extracts were obtained by treating the particulate fraction with a $0 \cdot 1 \%(\mathrm{v} / \mathrm{v})$ solution of Nonidet in $0 \cdot 6 \mathrm{M}$ sucrose + phosphate buffer and removing the particulate fragments by centrifugation for $30 \mathrm{~min}$. at $20,000 \mathrm{~g}$. A comparable fraction was similarly treated except the buffer did not contain Nonidet. The supernatant solutions were retained and the particulate deposits in each case taken up in a similar volume of buffer which contained $0.1 \%$ Nonidet to ensure complete activation of the bound enzymes When the Nonidet was added prior to centrifugation the glutamate-aspartate transaminase was quantitatively released or solubilized from the mitochondria whereas in the control lacking Nonidet the enzyme remained firmly attached to 
the mitochondria. Control experiments showed that the detergent did not inhibit or stimulate the enzyme.

\section{Coenzyme requirements}

The effect of pyridoxal phosphate $(10 \mu \mathrm{g}$. free acid $/ \mathrm{ml}$. reaction mixture) on glutamate-aspartate transaminase was examined. The addition of coenzyme had little effect on the undialysed enzyme but it did increase activity by $20 \%$ when the enzyme extract had been dialysed for several hours. Partial resolution of the transaminase into apoenzyme and coenzyme as a result of dialysis would account for this increase in activity.

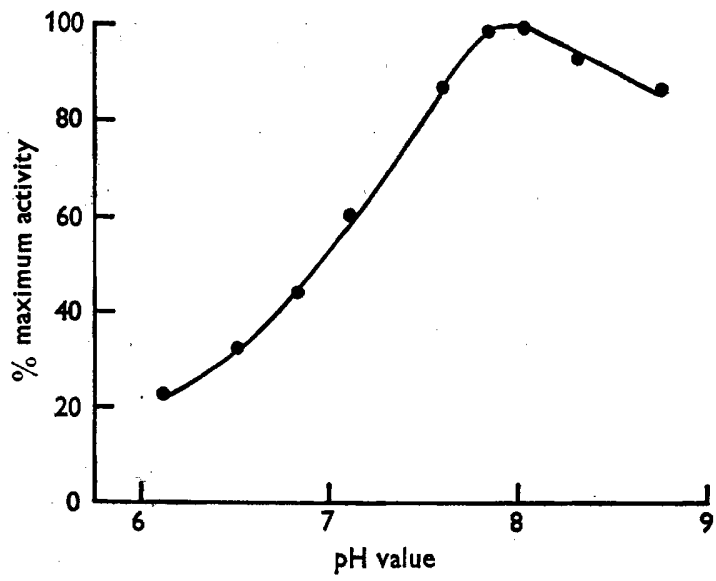

Fig. 1. The effect of $\mathrm{pH}$ on glutamate-aspartate transaminase. Reaction system as in Table 1. except for variation in $\mathrm{pH}$ value as indicated. Incubated at $32^{\circ}$ for $30 \mathrm{~min}$. Total volume $1 \mathrm{ml}$.

\section{$p H$ activity curve}

The activity of glutamate-aspartate transaminase was examined as a function of $\mathrm{pH}$ value. Activities were estimated from the rate of glutamic acid formation under the conditions described for the enzyme assay. In these determinations the final buffer concentration was $0.05 \mathrm{M}$ and the $\mathrm{pH}$ value of the reaction mixture was measured immediately after the assay. Phosphate buffer was used for $\mathrm{pH} \mathrm{6.0} \mathrm{to}$ $8 \cdot 0$ and borax + boric acid for $\mathrm{pH} 8 \cdot 0$ to $9 \cdot 0$. Initial reaction velocities are expressed as percentages of maximum activity. The activity curve is illustrated in Fig. 1 and shows that the enzyme has an optimum at $\mathrm{pH} \mathrm{7 \cdot 8-8 \cdot 0.}$

\section{Reversibility}

The reversibility of the glutamate-aspartate transaminase reaction was demonstrated by the formation of aspartate from glutamate and oxaloacetic acid (forward reaction) and by the formation of glutamate from aspartate and $\alpha$-ketoglutarate (reverse reaction). Progress curves of the forward and reverse reactions are shown in Fig. 2. The points on the curve were obtained by estimating glutamic acid and aspartic acid at each specified time. Equilibrium was reached in $3 \mathrm{hr}$. and this balanced system remained unchanged for a further $1 \mathrm{hr}$. The equilibrium was $60 \%$ in favour of the formation of glutamic acid (Aspartate $+\alpha$-ketoglutarate reaction). 
Calculation of the equilibrium constant for the reactions gives a value of

$$
\mathbf{K}=\frac{\text { (aspartate) }(\alpha \text {-ketoglutarate) }}{\text { (glutamate) (oxaloacetate) }}=2 \cdot 3 \text { at } \mathrm{pH} \mathbf{7 \cdot 9} \text { and } 32^{\circ} .
$$

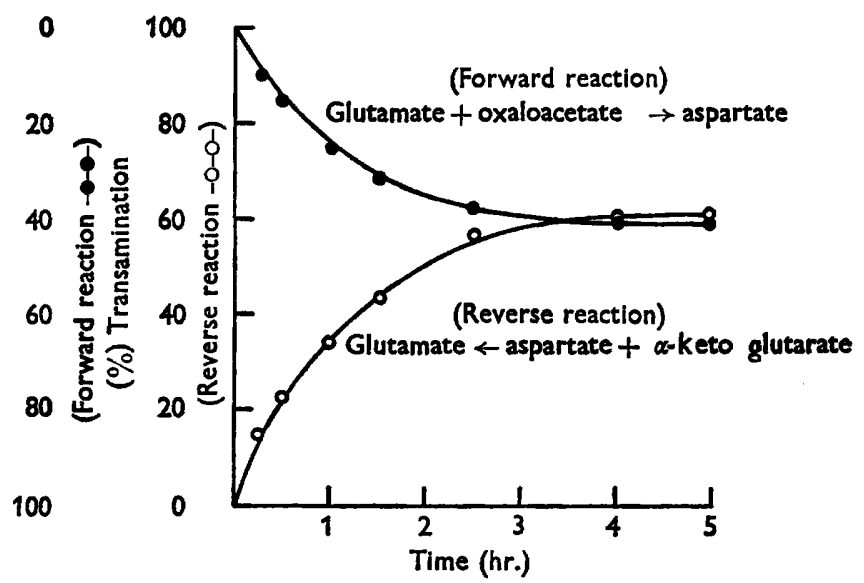

Fig. 2. Reversibility of glutamate-aspartate transaminase. Ordinate numbers on the right show percentage transamination measured by glutamic acid formation (reverse reaction (O)). Ordinate numbers on the left show percentage transamination measured by aspartic acid formation (forward reaction (O)). Reaction system contained: $10 \mu \mathrm{mole}$ L-amino acid; $30 \mu$ mole keto acid; $1 \mu$ mole pyridoxal phosphate; $0.4 \mathrm{ml}$. enzyme extract and potassium phosphate buffer containing $0.1 \%(\mathrm{v} / \mathrm{v})$ Nonidet P40, pH 7.9. Total volume $1 \mathrm{ml}$.; temp. $32^{\circ}$.

\section{DISCUSSION}

The results of these experiments demonstrate unequivocally that a wide variety of transaminase reactions occur in germinating uredospores of Puccinia helianthi and that in common with plant and animal tissue (Smith, 1962; Hird \& Rowsell, 1950) enzyme activity can be localized on a particulate fraction.

The reversibility of the glutamate-aspartate enzyme was demonstrated and the equilibrium constant at $\mathrm{pH} 7.9$ and $32^{\circ}$ was $2 \cdot 3$. This is in close agreement with the $2 \cdot 2$ obtained by Bigger-Gehring (1955) for the same enzyme from Saccharomyces cerevisiae. The uredospore enzyme showed optimum activity between $\mathrm{pH} 7 \cdot 8$ and 8.0. The effect of pyridoxal phosphate on the enzyme was small, though it seems that this compound is the coenzyme for all transaminase enzymes (Meister, 1957). The effect of pyridoxal phosphate on the dialysed enzyme suggests that some resolution into apoenzyme and coenzyme had occurred during the period of dialysis.

The presence of these transaminase enzymes in the uredospores would suggest that the uredospore could synthesize a wide variety of amino acids provided the corresponding keto acids and glutamic acid were available.

Several rust fungi can synthesize amino acids from extraneous carbohydrates (Kasting, McGinnis \& Broadfoot, 1959; Staples, Burchfield \& Baker, 1961 ; Reisener, McConnell \& Ledingham, 1961). Reisener et al. (1961) germinated uredospores of Puccinia graminis tritici on a solution containing valerate-1 $-{ }^{14} \mathrm{C}$ and demonstrated the incorporation of the labelled carbon into several amino acids, in particular glutamic acid, $\gamma$-aminobutyric acid, glutamine and alanine. The high activity of 
the $C_{1}$ in glutamate suggests that the valerate had undergone extensive $\beta$ oxidation to acetyl CoA which was subsequently metabolized via the tricarboxylic acid (TCA) cycle. Reisener et al. (1961) have suggested that the $\gamma$-aminobutyric acid may result from the enzymic decarboxylation of glutamic acid. However, this may not be so, since there is apparently no glutamic decarboxylase present in $P$. helianthi (Smith, 1959) and furthermore, there is a decrease in glutamic decarboxylase activity in several different rust-infected host-parasite complexes, including susceptible wheat infected with $\boldsymbol{P}$. graminis tritici (Smith, 1959).

In a comparative study of the metabolic capabilities of several obligately parasitic and saprophytic fungi (Staples et al. 1961), there is strong indication that the assimilate, in this case acetate-2-14 $\mathrm{C}$, is also metabolized by way of the TCA cycle since the first free and protein amino acids to be labelled are all closely associated with the cycle. Although labelled leucine and methionine, which are not directly associated with the TCA cycle, did eventually accumulate in the free amino acid pool of the obligate parasite Uromyces phaseoli, they were never incorporated into protein. Conversely, short-term incubation with L-leucine-U-14C and L-methionine${ }^{35} \mathrm{~S}$ did lead to the rapid incorporation of the labelled substance into the protein fraction. Further studies showed that $U$. phaseoli suffered a rapid loss in the mechanism for protein synthesis after wetting and this coupled with slow synthesis of leucine and methionine would account for the failure to detect labelling in the leucine and methionine in the protein fraction. Thus it would seem that the uredospores do have the mechanism for the synthesis of proteins but are restricted by their slowness or inability to synthesize the precursors of proteins.

The rapid synthesis of glutamic acid shown by uredospores of several rust fungi (Staples et al. 1961; Reisener et al. 1961) may be due to the activity of glutamic dehydrogenase since germinating uredospores of Puccina helianthi (Smith, 1959) contain a highly active glutamic dehydrogenase which catalyses the formation of glutamate from $\alpha$-ketoglutarate and ammonia. This enzyme plays a very significant part in metabolism as it serves not only as a port of entry for ammonia but also as a link between carbohydrate and nitrogen metabolism. Further metabolism of the glutamic acid by transamination could involve extensive interconversion of the amino group giving rise to a wide variety of amino acids. The limiting factor in this hypothesis would undoubtedly be the availability of keto acids, in particular the keto acids remote from the TCA cycle.

The failure to detect labelled carbon in certain amino acids and slow uptake of labelled carbon in others (Staples et al. 1961; Reisener et al. 1961) does not necessarily imply that these amino acids were not formed. On the assumption that glutamic acid is synthesized by reductive amination of $\alpha$-ketoglutaric acid and subsequently involved in a variety of transamination reactions, then the labelled carbon would not appear immediately in the new amino acid but in $\alpha$-ketoglutaric acid. Hence a labelled amino acid would be formed only when the labelled carbon had been previously incorporated into the corresponding keto acid.

Since uredospores can incorporate labelled carbon into 10 or 12 amino acids from extraneous carbohydrate after prolonged incubation (Kasting et al. 1959; Staples et al. 1961; Reisener et al. 1961) and assuming that transamination plays a major role in their synthesis, it seems safe to deduce that the uredospores are able to synthesize the corresponding keto acids. The apparent inability to synthesize 
certain amino acids and the relative slow synthesis of others may indicate that the parasite is dependent on the host for the supply of these amino acids or conversely on a supply of the corresponding keto acids. It has already been suggested that races of rust may differ in their specific amino acid requirements, in particular those amino acids which occur in very low concentrations (Samborski, Forsyth \& Person, 1958; Samborski \& Forsyth, 1960).

\section{REFERENCES}

Adams, E. Nomograph distributed by the California Corporation for Biochemical Research, Los Angeles 63, California, U.S.A.

Bigger-Gehring, L. (1955). Transamination reactions in Saccharomyces fragilis. J. gen. Microbiol. 13, 45.

Braunstein, A. E. \& Kritzmann, M. G. (1937). Über den Ab- und Aufbau von Aminosäuren durch Umaminierung. Enzymologia, 2, 129.

Farkas, G. L. \& Ledingham, G. A. (1959). Studies on the polyphenol-polyphenoloxidase system of wheat stem rust uredospores. Canad. J. Microbiol. 5, 141.

Fincham, J. R. S. \& Boulter, A. B. (1956). Effects of amino acids on transaminase production in Neurospora crassa: evidence for four different enzymes. Biochem. J. 62, 72.

HiRd, F. J. R. \& Rowsell, E. V. (1950). Additional transamination by insoluble particle preparations of rat liver. Nature, Lond. 166, 517.

Kasting, R., McGinnis, A. J. \& Broadfoot, W. C. (1959). Biosynthesis of some amino acids from sucrose by germinating uredospores of wheat stem rust, race 15 B. Nature, Lond., 184, 1943.

McCurdy, H. D. \& Cantino, E. C. (1960). Isocitritase, glycine-alanine transaminase, and development in Blastocladiella emersonii. Plant Physiol. 35, 463.

Meister, A. (1957). Biochemistry of the amino acids. New York: Academic Press Inc.

Reisener, H., McConneli, W. B. \& Ledingham, G. A. (1961). Studies on the metabolism of valerate-1-C ${ }^{14}$ by uredospores of wheat stem rust. Canad. J. Biochem. Physiol. 39, 1559 .

SACKSTON, W. E. (1960). Studies on sunflower rust. 11. Longevity of uredospores of Puccinia helianthi. Canad. J. Bot. 38, 883.

SAMBorski, D. J. \& Forsyth, F. R. (1960). Inhibition of rust development on detached wheat leaves by metabolites, antimetabolites, and enzyme poisons. Canad. J. Bot. 38, 467 .

Samborski, D. J., Forsyth, F. R. \& Person, C. (1958). Metabolic changes in detached wheat leaves floated on benzimidazole and the effect of these changes on rust reaction. Canad. J. Bot. 36, 591.

Sanwal, B. D. (1958). A study of transamination system in Fusarium. Experientia, 14, 246.

Sentheshanmuganathan, S. (1960). The purification and properties of the tyrosine-2oxoglutarate transaminase of Saccharomyces cerevisiae. Biochem. J. 77, 619.

Sмттн, J. E. (1959). Alterations in the activity of certain enzymes involved in the nitrogen metabolism of resistant and susceptible sunflower varieties associated with infection by Puccinia helianthi Schrw. Ph.D. Thesis, University of Manitoba, Canada.

Sмгтн, J. E. (1962). Mitochondrial transamination in sunflower hypocotyls. Biochem. Biophys. Acta, 57, 183.

Staples, R. C., Burchfield, H. P. \& Baker, J. G. (1961). Comparative biochemistry of obligately parasitic and saprophytic fungi. 1. Assimilation of $\mathrm{C}^{14}$-labeled substrates by nongerminating spores. Contr. Boyce Thompson Inst. 21, 97.

WAGNer, R. P., Bergquist, A. \& KARP, G. W. (1958). Some factors influencing valine and isoleucine transaminase activity in Neurospora crassa. Arch. Biochem. Biophys. 74, 182.

WAGNer, R. P. \& Ifland, P. W. (1956). Biochemical and physiological studies on a strain of Neurospora crassa inhibited by threonine. C.R. Lab. Carlsberg (Sér. physiol.), 26, 381. 